\title{
Report for Deciding Whether or not Sell Level Premium Products from YRT and Level Premium Models
}

\author{
Yibo Dai \\ Lucheng District, Wenzhou City, Zhejiang Province, China
}

\begin{abstract}
I am a student working in the life product development area of SLIC. Storrs Life has already begun to sell a 10-year Yearly Renewable Term Insurance (YRT) product for female age 40 non-smoker, but recently the sales are reduced because the competitor become to sell a product called Level Premium Product. Then SLIC decide whether or not Storrs Life should begin to sell Level Premium tern product to those female age 40 non-smoker. In this situation, though the data given, I build two models for the YRT and Level Premium Product. Also, I did the sensitivity test of earned interest rate, average face amount and so on for both of the products. By comparison of two products, I recommend SLIC should begin to sell Level Premium.
\end{abstract}

Keywords: Insurance, Competition, Level premium/YRT.

\section{Base Pricing Assumptions and Base-case risk-adjusted IRR}

From the information given, we know that the competitors of Storrs Life Insurance Company begin to sell the Level Premium Product at the price of 2.4 dollars per thousand of face amount for females age 40 who do not smoke. However, I calculate the Level Premium could be sell at 2.38 dollars per thousands of face amount through the factors, Number of policies sold and Average Face amount Per Policy and so on, which are all the same as the our YRT model's factors. Since the company could sell cheaper than the other companies with the same product and service, the other company will face the adverse selection, the customers will choose the cheaper one. So, the company has the advantages to sell the Level Premium Product in the pricing. In this case, I would recommend company begin to sell Level Premium Term Product.

A break-even analysis determines the value of a key assumption that results in a net present value of zero when discounting the cash flows at the opportunity cost of capital. When the assumptions value is lower than the Breakeven point, which means that the adjusted rate of return would lower than OCC. In this case, the company will make negative cash flows, so company may cannot payout the benefits and expenses, so the company would face the risk of bankrupt. A scenario test shows the effect key drivers have on net present value and IRR by changing more than one key assumption at the same time. These two assumptions must have some relationships or they need to be dependent. When one of the assumptions is impacted, the scenario test will show how other key assumptions will move to lead the final Adjusted IRR change. A Sensitivity test shows the effect on net present value and IRR by changing one key variable and keeping the others the same. I did the sensitivity test for earned interest rate, average face amount, lapse rate in $1^{\text {st }}$ year, lapse rate in $2^{\text {nd }}-9^{\text {th }}$ year and mortality factor since I think it is the base of the company, if the company do not have the clearly average face amount, earned interest rate, lapse rate or mortality factor, the company cannot price the premium correctly. Through sensitivity tests, I found that the earned interest rate, $2^{\text {nd }}-9^{\text {th }}$ year lapse rate and mortality factor do have significant impact on the final Adjusted Internal Rate of Return. Here is my explanation.

\section{Discussion of Sensitivity Test Results}

\begin{tabular}{|c|c|c|}
\hline Earned Interest Rate & $\begin{array}{c}\text { Risk Adjusted } \\
\text { IRR(YRT) }\end{array}$ & Risk Adjusted IRR(LP) \\
\hline $0 \%$ & $11.44 \%$ & $4.81 \%$ \\
\hline $2 \%$ & $13.15 \%$ & $9.66 \%$ \\
\hline $4 \%$ & $14.81 \%$ & $14.36 \%$ \\
\hline $6 \%$ & $16.43 \%$ & $18.92 \%$ \\
\hline $8 \%$ & $18.00 \%$ & $23.33 \%$ \\
\hline $10 \%$ & $19.52 \%$ & $27.63 \%$ \\
\hline $12 \%$ & $21.02 \%$ & $31.81 \%$ \\
\hline $14 \%$ & $22.47 \%$ & $35.90 \%$ \\
\hline $16 \%$ & $23.89 \%$ & $39.91 \%$ \\
\hline $18 \%$ & $25.28 \%$ & $43.85 \%$ \\
\hline $20 \%$ & $26.64 \%$ & $47.73 \%$ \\
\hline
\end{tabular}

History shows that interest rates can fluctuate quite a bit even over short-term time periods and certainly within 10-year periods. During the research, I found that the highest United States Fed Fund Rate is about $20 \%$ in 1980 s, so it is possible for us to choose the upper bound at $20 \%$. Also, during the research, I found that the term 2008 to the term 2016, the interest is approximate to zero, so it is also making sense for us to analysis the interest rate in $0 \%$. Through the sensitivity test I did for the Earned Interest Rate (table above), I found that as the earned interest rate increase, both for the YRT and Level Premium's Risk Adjusted Internal Rate of Return moves upward. From the table, we could clearly discover that the Risk Adjusted IRR for both products increasing dramatically when the earned interest rate is increasing. So, we could easily know that the Earned interest rate is a significant risk factor for either product. Risk Adjusted Internal Rate of Return would be changed since the change of Earned Interest rate will impact a lot of factors. Taking an example about the factor that all models will have influence, as the earned interest rate increase, the Net Investment Income would increase. The increase of investment will influence the total income and After-tax income. As the Net investment income and the After-tax interest earned on Benchmark Surplus increase, the total distributable earnings are increased. "The total distributable earnings" is a key factor which will influence the Risk Adjusted IRR. In this situation, the return 
would be higher, which means the Risk Adjustment Internal Rate of Return will increase. However, we can clearly find that the influence on Level Premium's Risk Adjusted IRR more than the YRT's. The reason is that Level Premium is more volatile since the Level Premium has the reserves and YRT does not. The assets supporting these reserves earn interest. The other resources, such as Benchmark Surplus, are common to both YRT and Level Premium, so they have the same conditions except Reserves. That's the reason that as the Earned Interest Rate increasing, Level Premiums has more impact on Risk Adjusted IRR than YRT's. Also, from the table above, we can find that the Risk Adjusted return of Level Premium is lower than the Risk Adjusted IRR of YRT if the earned interest rate is less than $4.3 \%$, so if the company decide to sell the Level Premium Term Product, it still has the risk when the Earned Interest rate is lower than $4.3 \%$. If the interest is lower, the customers would like to choose the YRT product, since the product can produce higher return. Absolutely, the company can decide to sell the Level Premium Term Product when the Earned Interest rate is high. But high return also means high risk, if the return cannot reach the customers' expected return, the company also face the problem of adverse selection since there is the higher return product existing. Also, when the Earned Interest Rate lower than $3.414 \%$, we have a crucial problem, which is the return is lower than the opportunity cost of capital. However, if the earned interest rate is lower than the $3.414 \%$, the rate must be lower than $4.3 \%$, so the product had already lower than the expected return. In this case, customers would like to choose other products. Also, for the YRT product, it also faces the risk that the return is lower than the Opportunity cost of capital (13\%) if the earned interest rate is lower than $1.82 \%$, although it has lower possible occur.

\begin{tabular}{|c|c|c|}
\hline Average Face Amount & $\begin{array}{c}\text { Risk Adjusted } \\
\text { IRR(YRT) }\end{array}$ & Risk Adjusted IRR(LP) \\
\hline 250000 & $13.96 \%$ & $13.75 \%$ \\
\hline 260000 & $14.21 \%$ & $14.04 \%$ \\
\hline 270000 & $14.44 \%$ & $14.32 \%$ \\
\hline 280000 & $14.66 \%$ & $14.58 \%$ \\
\hline 290000 & $14.86 \%$ & $14.82 \%$ \\
\hline 300000 & $15.06 \%$ & $15.06 \%$ \\
\hline 310000 & $15.24 \%$ & $15.28 \%$ \\
\hline 320000 & $15.41 \%$ & $15.49 \%$ \\
\hline 330000 & $15.58 \%$ & $15.69 \%$ \\
\hline 340000 & $15.73 \%$ & $15.88 \%$ \\
\hline 350000 & $15.88 \%$ & $16.06 \%$ \\
\hline
\end{tabular}

When I do the sensitivity test for the average face amount, I found that the average face amount has small impact on the both the Risk Adjusted Internal Risk Return of YRT product and the Level Premium. Although the face amount will affect many factors, such as premiums, net investment income, some expenses, some of these factors will be reduced when calculated the pre-tax income. In this case, both for these two products, no matter how large the change the Average Face Amount change, the Risk Adjusted IRR will not change too much, so we can know that the risk is very similar for both products. From the table, apparently, we can find that as the average face amount increase, the Risk Adjusted Internal Rate of Return also increase for both YRT and Level Premium Product. As the average face amount increase, the premium will increase. In this situation, company could receive more money, then company could use this money to have investments which will cause the higher net investment income. The same as the earned interest rate, when the net investment income increasing, the distributable earnings, which is influenced Risk Adjusted IRR will increase when the income increase. Although average face amount can make the Risk Adjusted IRR float up and down, we can see that the Risk Adjusted IRR change a little bit as the average face amount increasing or decreasing, so average face amount is not a very important factor to affect the Risk Adjusted IRR. Also, there also existing the risks for both products, when face amount lower than a fixed amount. In the YRT product, when the average face amount is lower than 217000 , the Adjusted Rate of Return will be lower than the Opportunity Cost of Capital; In the Level Premium Product, when the average face amount is lower than 226500, the Adjusted Rate of Return will lower than the Opportunity Cost of Capital. Although the Average Face Amount is a minor risk with similar risk profiles by products, when the average amount increase, it also helps the Level Premium to get higher Adjusted Internal Rate of Return. When the Average Face Amount is larger than 300000, the Risk Adjusted Internal Rate of Return for Level Premium begin to larger than the YRT's. If the company could receive the average face amount larger than 300000, it is better for Level Premium. But if the average face amount is lower than 300000, it just influences a little bit in Risk Adjusted IRR, so that the reason I would recommend the Level Premium Products here.

\begin{tabular}{|c|c|c|}
\hline Lapse Rate 1st Year & $\begin{array}{c}\text { Risk Adjusted } \\
\text { IRR(YRT) }\end{array}$ & Risk Adjusted IRR(LP) \\
\hline $15 \%$ & $16.22 \%$ & $15.75 \%$ \\
\hline $16 \%$ & $15.99 \%$ & $15.61 \%$ \\
\hline $17 \%$ & $15.76 \%$ & $15.48 \%$ \\
\hline $18 \%$ & $15.53 \%$ & $15.34 \%$ \\
\hline $19 \%$ & $15.29 \%$ & $15.20 \%$ \\
\hline $20 \%$ & $15.06 \%$ & $15.06 \%$ \\
\hline $21 \%$ & $14.82 \%$ & $14.91 \%$ \\
\hline $22 \%$ & $14.58 \%$ & $14.76 \%$ \\
\hline $23 \%$ & $14.34 \%$ & $14.61 \%$ \\
\hline $24 \%$ & $14.09 \%$ & $14.46 \%$ \\
\hline $25 \%$ & $13.85 \%$ & $14.31 \%$ \\
\hline & & \\
\hline Lapse Rate & Risk Adjusted & Risk Adjusted IRR(LP) \\
\hline 2 nd-9thYear & IRR(YRT) & $10.26 \%$ \\
\hline $5 \%$ & $18.80 \%$ & $11.28 \%$ \\
\hline $6 \%$ & $18.05 \%$ & $12.27 \%$ \\
\hline $7 \%$ & $17.31 \%$ & $13.23 \%$ \\
\hline $8 \%$ & $16.56 \%$ & $14.16 \%$ \\
\hline $9 \%$ & $15.81 \%$ & $15.06 \%$ \\
\hline $10 \%$ & $15.06 \%$ & $15.92 \%$ \\
\hline $11 \%$ & $14.31 \%$ & $16.76 \%$ \\
\hline $12 \%$ & $13.55 \%$ & $17.56 \%$ \\
\hline $13 \%$ & $12.80 \%$ & $18.34 \%$ \\
\hline $14 \%$ & $12.05 \%$ & $19.08 \%$ \\
\hline $15 \%$ & $11.29 \%$ & \\
\hline & & \\
\hline
\end{tabular}

From the table above, they are the sensitivity test for the lapse rate $1^{\text {st }}$ year and the lapse rate between the $2^{\text {nd }}$ year and $9^{\text {th }}$ year. For the $1^{\text {st }}$ year lapse rate, when the rate is decreasing, both the YRT and Level Premium of Risk Adjusted Rate of Return are decreasing. It makes sense for the risk adjusted IRR decreases when the lapse rate increases because when the lapse rate rises, company will receive less premium, in this case, the company will have less money or opportunity to invest, the company will make less net investment income and then the adjusted IRR will fall. Also, for both products the future year premiums are sufficient to pay benefits and expenses and have a profit remaining. So, if more people lapse, fewer of these profits are earned by company. Because the initial investment in Year 1 does not change, the Risk Adjusted IRR will decrease. Also, after I did the breakeven test, I found that if 
the Risk Adjusted IRR need to be higher than Opportunity Cost of Capital, the $1^{\text {st }}$ year lapse rate should be higher than $28.37 \%$ for YRT, and $32.9 \%$ for Level Premium. It's an impossible number for YRT and Level Premium to reach. Also, as we can see from the table, as the $1^{\text {st }}$ year lapse rate increasing, the IRR decrease tiny, which means that the $1^{\text {st }}$ year lapse rate is not so significant risk for both products to make Risk Adjusted IRR move up and down dramatically. But for Lapse rate in 2-9 years, we can see that the Adjusted IRR in Level Premium and YRT have crucial effect by changing the lapse rate. When the lapse rate decreases in the 2-9 years, the Risk Adjusted IRR increases in the YRT model, the reason is that lower lapse rate would cause more net investment income, and then make more distributable earnings. Finally, company will generate higher Adjusted IRR. For YRT, the same as lapse rate $1^{\text {st }}$ year, the future premiums are sufficient to pay benefits and expenses and have a profit remaining, so if more people lapse, fewer of these profits are earned by company, the Risk Adjusted IRR would reduce when the initial investment is keeping the same. However, for the Level Premium rate, the lower lapse rate will cause lower Risk Adjusted IRR. The reason is when the lapse rate decrease, the change of reserve will increase a lot, which will cause the income decrease a lot. Also, Level Premium has insufficient premiums to pay out the benefits and expenses in the future years. So, if there are more lapse means that companies will have the smaller negative cash flows in those years, and then the Risk Adjusted IRR would increase. That's also the reason I would make a recommendation to sell the Level Premium Product, since the $1^{\text {st }}$ year lapse rate is not an important factor, and if the $2^{\text {nd }}-9^{\text {th }}$ year lapse rate reduce, it is benefit for level premium; if the rate keep the same, it also can be accepted by the company.

\begin{tabular}{|c|c|c|}
\hline Mortality Factor & $\begin{array}{c}\text { Risk Adjusted } \\
\text { IRR(YRT) }\end{array}$ & Risk Adjusted IRR(LP) \\
\hline 0.95 & $20.59 \%$ & $20.53 \%$ \\
\hline 0.96 & $19.47 \%$ & $19.44 \%$ \\
\hline 0.97 & $18.36 \%$ & $18.34 \%$ \\
\hline 0.98 & $17.25 \%$ & $17.25 \%$ \\
\hline 0.99 & $16.15 \%$ & $16.15 \%$ \\
\hline 1 & $15.06 \%$ & $15.06 \%$ \\
\hline 1.01 & $13.97 \%$ & $13.95 \%$ \\
\hline 1.02 & $12.88 \%$ & $12.85 \%$ \\
\hline 1.03 & $11.80 \%$ & $11.74 \%$ \\
\hline 1.04 & $10.72 \%$ & $10.62 \%$ \\
\hline 1.05 & $9.65 \%$ & $9.50 \%$ \\
\hline
\end{tabular}

From the table above, it is the sensitivity for the Mortality factor. Since it is not reasonable for mortality doubles, I only did the mortality sensitivity test under 2 , and it clearly shows that when the mortality factor increases, both the product's Risk Adjusted IRR are decreasing. The main reason for IRR falls when mortality rises is that there are more death benefits paid by the company; the IRR rises as mortality falls because

\begin{tabular}{|c|c|c|c|c|c|}
\hline \\
\hline \multicolumn{6}{|l|}{ YRT } \\
\hline \multirow{12}{*}{ Mortality Factor } & $15.06 \%$ & $5 \%$ & $6.00 \%$ & $7.00 \%$ & $8.00 \%$ \\
\hline & 0.95 & $24.59 \%$ & $23.79 \%$ & $22.99 \%$ & $22.19 \%$ \\
\hline & 0.96 & $23.42 \%$ & $22.63 \%$ & $21.84 \%$ & $21.05 \%$ \\
\hline & 0.97 & $22.26 \%$ & $21.48 \%$ & $20.70 \%$ & $19.92 \%$ \\
\hline & 0.98 & $21.10 \%$ & $20.33 \%$ & $19.56 \%$ & $18.79 \%$ \\
\hline & 0.99 & $19.95 \%$ & $19.19 \%$ & $18.43 \%$ & $17.67 \%$ \\
\hline & 1 & $18.80 \%$ & $18.05 \%$ & $17.31 \%$ & $16.56 \%$ \\
\hline & 1.01 & $17.65 \%$ & $16.92 \%$ & $16.18 \%$ & $15.45 \%$ \\
\hline & 1.02 & $16.51 \%$ & $15.79 \%$ & $15.06 \%$ & $14.34 \%$ \\
\hline & 1.03 & $15.37 \%$ & $14.66 \%$ & $13.95 \%$ & $13.23 \%$ \\
\hline & 1.04 & $14.23 \%$ & $13.53 \%$ & $12.83 \%$ & $12.13 \%$ \\
\hline & 1.05 & $13.09 \%$ & $12.41 \%$ & $11.72 \%$ & $11.03 \%$ \\
\hline
\end{tabular}

there are less death benefits paid than expected. From the table above, we can see that when the mortality factor changes a little bit, the Risk Adjusted IRR would have significant change in value, so the mortality factor is a significant risk factor for both products. However, as we can see, no matter how the rate changes, the Adjusted IRR for YRT and Level Premium are similar, they both have the close value on adjusted IRR. For the Mortality Factor, both of products face the risk that when the Mortality rate is lower than 1.019, the rate of return would lower than the OCC.

As I mentioned before, both of products face the risk when earned premium, average face amount, lapse rate and mortality rate lower than a fixed amount, the products' Adjusted IRR would lower than the OCC. When the Adjusted IRR lower than the OCC, which would cause the result that the company would make negative cash flows. In this case, companies cannot make profits and cannot payout the benefits and expenses, so the company would face the risk of bankrupt. To solve the problem, I suggest that the company could make more reserve to prevent the risk happened. However, making more reserves would cause less money could be used to invest, that also would make the IRR lower. So we could sell the Level Premium at the 2.39 dollars per thousands of face amount, not only we have the lower pricing amount than the competitors and would be adverse selected from customers, but we also can make more money. In this case, we can increase the reserve amount to prevent the risk happens.

\section{Discuss Scenario Test(s) Results}

From the table below, I choose the Mortality Factor and $2^{\text {nd }}-9^{\text {th }}$ year Lapse Rate to do the scenario test. I found there is relation between Mortality Factor and $2^{\text {nd }}-9^{\text {th }}$ year Lapse Rate. Taking Covid-19 as an example to explain the dependence between the Mortality Factor and $2^{\text {nd }}-9^{\text {th }}$ year Lapse Rate, many people suffering from covid-19. At first, the medical department cannot find the true reason, and cannot give the right Medicare. In this case, more people would keep their policy in force while the pandemic is driving up the mortality rate because insureds would want to be protected against a premature death. As we can see that when both the lapse rate and mortality factor go up in YRT product, the Adjusted Rate of Return would decrease. As I said before, more people leave or die, fewer profits the company could earn, as the initial investment does not change, the IRR would reduce. But as we can see from the table for Level Premium, as the mortality goes up, the lapse rate goes down, and the Adjusted IRR would decrease. The reason is that Level Premium would have insufficient premiums in the later years to pay benefits and expenses, so more lapse means smaller negative cash flows.

\begin{tabular}{|r|r|r|r|r|r|r|}
\hline apse Rates 2-9 years & & & & \\
\hline $\mathbf{9 . 0 0 \%}$ & $10.00 \%$ & $11.00 \%$ & $12.00 \%$ & $13.00 \%$ & $14.00 \%$ & $15.00 \%$ \\
\hline $21.39 \%$ & $20.59 \%$ & $19.78 \%$ & $18.98 \%$ & $18.18 \%$ & $17.37 \%$ & $16.57 \%$ \\
\hline $\mathbf{2 0 . 2 6 \%}$ & $19.47 \%$ & $18.67 \%$ & $17.88 \%$ & $17.09 \%$ & $16.29 \%$ & $15.50 \%$ \\
\hline $18.02 \%$ & $18.36 \%$ & $17.57 \%$ & $16.79 \%$ & $16.01 \%$ & $15.22 \%$ & $14.44 \%$ \\
\hline $16.91 \%$ & $16.15 \%$ & $16.48 \%$ & $15.70 \%$ & $14.93 \%$ & $14.16 \%$ & $13.38 \%$ \\
\hline $15.81 \%$ & $15.06 \%$ & $14.31 \%$ & $14.63 \%$ & $13.86 \%$ & $13.10 \%$ & $12.33 \%$ \\
\hline $14.71 \%$ & $13.97 \%$ & $13.23 \%$ & $12.49 \%$ & $12.80 \%$ & $12.05 \%$ & $11.29 \%$ \\
\hline $13.61 \%$ & $12.88 \%$ & $12.15 \%$ & $11.42 \%$ & $10.69 \%$ & $11.00 \%$ & $10.26 \%$ \\
\hline $12.52 \%$ & $11.80 \%$ & $11.08 \%$ & $10.37 \%$ & $9.65 \%$ & $8.92 \%$ & $9.23 \%$ \\
\hline $11.43 \%$ & $10.72 \%$ & $10.02 \%$ & $9.31 \%$ & $8.60 \%$ & $7.89 \%$ & $7.18 \%$ \\
\hline $10.34 \%$ & $9.65 \%$ & $8.95 \%$ & $8.26 \%$ & $7.56 \%$ & $6.87 \%$ & $6.17 \%$ \\
\hline
\end{tabular}




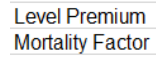

\begin{tabular}{|r|r|r|r|}
\hline $15.06 \%$ & $5 \%$ & $6.00 \%$ & $7.00 \%$ \\
\hline 0.95 & $16.16 \%$ & $17.09 \%$ & $17.99 \%$ \\
\hline 0.96 & $15.00 \%$ & $15.94 \%$ & $16.85 \%$ \\
\hline 0.97 & $13.82 \%$ & $14.78 \%$ & $15.71 \%$ \\
\hline 0.98 & $12.64 \%$ & $13.62 \%$ & $14.57 \%$ \\
\hline 0.99 & $11.45 \%$ & $12.45 \%$ & $13.42 \%$ \\
\hline 1 & $10.26 \%$ & $11.28 \%$ & $12.27 \%$ \\
\hline 1.01 & $9.06 \%$ & $10.10 \%$ & $11.11 \%$ \\
\hline 1.02 & $7.84 \%$ & $8.91 \%$ & $9.94 \%$ \\
\hline 1.03 & $6.62 \%$ & $7.71 \%$ & $8.76 \%$ \\
\hline 1.04 & $5.38 \%$ & $6.50 \%$ & $7.58 \%$ \\
\hline 1.05 & $4.14 \%$ & $5.27 \%$ & $6.38 \%$ \\
\hline
\end{tabular}

\section{Conclusion and Recommendation}

I totally agree that the company deicide to sell the Level Premium Term Policy. From the model I built, we can see that the pricing should be 2.38 dollars per thousands of face amount. In this pricing, the Adjusted return is higher than the $13 \%$, which is the OCC. In this case, the company makes the positive cash flows. The company could make profit. Also, 2.38 is less than 2.40 , so in my point of view, the company has the pricing advantages. So, the competitor will face the risk of adverse selection. Customers would like to choose the price which is lower for the same policy with the same service. Besides, from the sensitivity test, As I mentioned before, the average face amount, $1^{\text {st }}$ year lapse rate are not important
Lapse Rates $2-9$ years

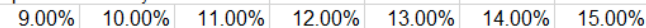

\begin{tabular}{|l|l|l|l|l|l|l|}
\hline $19.71 \%$ & $20.53 \%$ & $21.32 \%$ & $22.09 \%$ & $22.83 \%$ & $23.55 \%$ & $24.24 \%$ \\
\hline
\end{tabular}

\begin{tabular}{|l|l|l|l|l|l|l|l|}
\hline $18.60 \%$ & $19.44 \%$ & $20.24 \%$ & $21.02 \%$ & $21.78 \%$ & $22.50 \%$ & $23.20 \%$ \\
\hline
\end{tabular}

\begin{tabular}{|l|l|l|l|l|l|l|l|}
\hline $17.49 \%$ & $18.34 \%$ & $19.16 \%$ & $19.96 \%$ & $20.72 \%$ & $21.46 \%$ & $22.17 \%$ \\
\hline
\end{tabular}

\begin{tabular}{|l|l|l|l|l|l|l|l|}
\hline $16.38 \%$ & $17.25 \%$ & $18.08 \%$ & $18.89 \%$ & $19.67 \%$ & $20.41 \%$ & $21.14 \%$ \\
\hline
\end{tabular}

\begin{tabular}{|l|l|l|l|l|l|l|}
\hline $15.27 \%$ & $16.15 \%$ & $17.00 \%$ & $17.82 \%$ & $18.61 \%$ & $19.38 \%$ & $20.11 \%$ \\
\hline
\end{tabular}

\begin{tabular}{|l|l|l|l|l|l|l|}
\hline $14.16 \%$ & $15.06 \%$ & $15.92 \%$ & $16.76 \%$ & $17.56 \%$ & $18.34 \%$ & $19.08 \%$ \\
\hline
\end{tabular}

\begin{tabular}{|l|l|l|l|l|l|l|}
$13.04 \%$ & $13.95 \%$ & $14.84 \%$ & $15.69 \%$ & $16.51 \%$ & $17.30 \%$ & $18.06 \%$ \\
\hline
\end{tabular}

\begin{tabular}{|l|l|l|l|l|l|l|}
\hline $11.91 \%$ & $12.85 \%$ & $13.75 \%$ & $14.62 \%$ & $15.46 \%$ & $16.26 \%$ & $17.03 \%$ \\
\hline
\end{tabular}

\begin{tabular}{|r|r|r|r|r|r|r|}
\hline $10.78 \%$ & $11.74 \%$ & $12.66 \%$ & $13.55 \%$ & $14.40 \%$ & $15.22 \%$ & $16.01 \%$ \\
\hline $9.64 \%$ & $10.62 \%$ & $11.57 \%$ & $12.48 \%$ & $13.35 \%$ & $14.18 \%$ & $14.99 \%$ \\
\hline
\end{tabular}

\begin{tabular}{|r|r|r|r|r|r|r|}
\hline $9.64 \%$ & $10.62 \%$ & $11.57 \%$ & $12.48 \%$ & $13.35 \%$ & $14.18 \%$ & $14.99 \%$ \\
\hline $8.50 \%$ & $9.50 \%$ & $10.47 \%$ & $11.40 \%$ & $12.29 \%$ & $13.14 \%$ & $13.90 \%$ \\
\hline
\end{tabular}

factors, they would change the Adjusted IRR less than the other factors. For the earned interest rate, lapse rate in $2^{\text {nd }}-9^{\text {th }}$ year and so on, these factors have more impact on Adjusted IRR. However, these factors are all helpful for the Level Premium Product. For example, as the earned interest rate goes higher, the Adjusted return is elastic, the rate would go higher, and the growth rate is large. So, it is helpful for the company. But the company still has the risks that if these factors lower than the breakeven point. The company would face the risk of bankrupt, so I would recommend the company to increase more reserves to prevent the risk happens. All in all, the advantages outweigh the disadvantages, so I would recommend that the company begin to sell the Level Premium Term Policy.

\section{YRT Model}

\begin{tabular}{|c|c|c|c|c|c|c|c|c|c|c|c|}
\hline \multicolumn{12}{|l|}{ Ten Year Tem Insurance Female 40 Smoker } \\
\hline Input thems: (rows 1-21) & & & & Section & 1 & Input Items & & & & & \\
\hline Number of Policies Sold & 100,000 & & & & & & & & & & \\
\hline Avergege Face amount Per Policy & 300,000 & & & & & & & & & & \\
\hline Eamed Interest Rate & $4.3 \%$ & $4.3 \%$ & $4.3 \%$ & $4.3 \%$ & $4.3 \%$ & $4.3 \%$ & $4.3 \%$ & $4.3 \%$ & $4.3 \%$ & 4.3\% & \\
\hline Expenses & & & & & & & & & & & \\
\hline Acquisition Expense Per Polizy & 50 & & & & & & & & & & \\
\hline Acquisition Expense Pes $\$ 1000$ frce amount & 0.25 & & & & & & & & & & \\
\hline Maniterance Expense Pe Policy Per year & 10 & & & & & & & & & & \\
\hline Maintenance Expense Pe $\$ 1000$ inforce & 0.05 & & & & & & & & & & \\
\hline Tax rate & $21 \%$ & & & & & & & & & & \\
\hline Yeas & 1 & 2 & 3 & 4 & 5 & 6 & 7 & 8 & 9 & 10 & \\
\hline Prenium pes $\$ 1000$ & $1.07 \$$ & $1.33 \mathrm{~s}$ & 1.62 & $1.95 \mathrm{~s}$ & $2.32 \$$ & $2.76 \mathrm{~s}$ & $3.24 \mathrm{~s}-2 \mathrm{~s}-\mathrm{s}$ & 3.76 & $4.35 \mathrm{~s}$ & 4.97 & \\
\hline First vear lapse rate & $20.00 \%$ & & & & & & & & & & \\
\hline Renenal Years Lapse rates & & $10.00 \%$ & $10.00 \%$ & $10.00 \%$ & $10.00 \%$ & $10.00 \%$ & $10.00 \%$ & $10.00 \%$ & $10.00 \%$ & $100.00 \%$ & \\
\hline First vera Comission nte & $70.00 \%$ & & & & & & & & & & \\
\hline Reneval Commission atte & & $5 \%$ & $5 \%$ & $5 \%$ & $5 \%$ & $5 \%$ & $5 \%$ & $5 \%$ & $5 \%$ & $5 \%$ & \\
\hline Age & 40 & 41 & 42 & 43 & 44 & 45 & 46 & 47 & 48 & 49 & \\
\hline Best Estimate mortaliny rite & 0.00079722 & 0.00098262 & 0.0012051 & 0.00146466 & 0.00175203 & 0.00208575 & 0.00245655 & 0.00286443 & 0.00331866 & 0.0038007 & \\
\hline Benchmak Suplus a \& of erpetted one year clàm & $25 \%$ & & & & & & & & & & \\
\hline Notes and assumptions: & & & & & & & & & & & \\
\hline Timing of Cash Flows: & Premiums and acquisit & tion expenses lincl cor & :ommissions) are paid & id at the beginning of th & the ver & & & & & & \\
\hline & Death beneits and main & intenance expenses occ. & eccur unifomly throug & vghout the year & & & & & & & \\
\hline & & & & Section & 2 & Intermediate C & Calculations & & & & \\
\hline Beginning of Year & 1 & 2 & 3 & 4 & 5 & 6 & 7 & 8 & 9 & 10 & 11 \\
\hline Number of policies in fore & 100,000 & $79,936.22$ & $71,871.91$ & $64,606.77$ & $58,060.92$ & $52,163.28$ & $46,849.03$ & $42,060.55$ & $37,746.06$ & $33,858.72$ & .00 \\
\hline Free Amount ti fore & $\$ 30,000,000,000 \$$ & $\$ 23,980,866,720$ \$ & $\$ 21,561,572,377$ & $\$ 19,382,029,673 \$$ & $\$ 17,418,277,431$ \$ & $\$ 15,648,984,077 \$$ & $\$ 14,054,709,788$ \$ & $\$ 12,618,165,322$ & $\$ 11,323,819,323 \$$ & $\$ 10,157,615,475$ & $\cdot$ \\
\hline Statutory Income Sitatenent-Cash Flows & & & & Section & 3 & Statutory Incon & me & & & & \\
\hline Yeer & 1 & 2 & 3 & 4 & 5 & 6 & 7 & 8 & 9 & 10 & 11 \\
\hline Preniums & $32,100,000$ & $31,894,553$ & $34,929,747$ & $37,794,958$ & $40,410,404$ & $43,191,196$ & $45,537,260$ & $47,444,302$ & $49,258,614$ & $50,483,349$ & \\
\hline Net Investment thcome & $|(691,367)|$ & $753,299.06$ & $829,596.23$ & $898,854.10$ & $963,434,33$ & $1,034,565.42$ & $1,092,704.61$ & $1,138,399.37$ & $1,183,957.89$ & $1,214,015.69$ & . \\
\hline Sub-total-income & $5 \quad 31,408,633$ & & & & & & & & & & \\
\hline Death Benefis Paid & \$ $\quad 23,916,600$ \$ & $23,564,079 \$$ & $25,983,851$ & $28,388,084 \$$ & $30,517,345 \$$ & $32,639,869 \mathrm{~s}$ & $34,526,097 \mathrm{~s}$ & $36,143,851$ & $37,579,906 \mathrm{~s}$ & $38,606,049$ s & . \\
\hline Expense: & & & & & & & & & & & \\
\hline Acquisition & $12,500,000$ & & & & & & & & & & \\
\hline Maintenance & $2,500,000 \mathrm{~s}$ & $1,998,406 \mathrm{~s}$ & $1,796,798$ & $1,615,169 \mathrm{~s}$ & $1,451,523 \mathrm{~s}$ & $1,304,082 \$$ & $1,171,226 \mathrm{~s}$ & $1,051,514$ & $943,652 \$$ & $846,468 \mathrm{~s}$ & - \\
\hline Commissions & $22,470,000 \mathrm{~s}$ & $1,594,728 \mathrm{~s}$ & $1,746,487$ & $1,889,748 \mathrm{~s}$ & $2,020,520 \mathrm{~s}$ & $2,159,560 \$$ & $2,276,863$ & $2,372,215$ & $2,462,931 \mathrm{~s}$ & $2,524,167$ & \$ \\
\hline Change in Reseve & . 5 & . 5 & - & . $\$$ & . & . $\$$ & . & - & . $\$$ & . s s r or & $\$$ \\
\hline Sub-total-benefits and expenses & s $61,386,600$ s & $27,157,212 \mathrm{~s}$ & $29,527,136$ & $31,893,001 \mathrm{~s}$ & $33,989,388 \mathrm{~S}$ & $36,103,510 \mathrm{~s}$ & $37,974,186 \mathrm{~s}$ & $39,567,580$ & $40,986,489 \mathrm{~s}$ & $41,976,685$ & . \\
\hline Pretar income & {$[22,977,967)$ \& } & $5,490,639 \mathrm{~s}$ & $6,232,208$ & $6,800,811 \mathrm{~s}$ & $7,384,450 \mathrm{~s}$ & $8,122,251 \mathrm{~s}$ & $8,655,778$ s & $9,015,121$ & $9,456,083 \$$ & $9,720,680 \leqslant$ & . \\
\hline Tares & $\$ \quad(6,295,373)$ \$ & $1,153,034 \mathrm{~s}$ & $1,308,764$ & $1,428,170 \mathrm{~s}$ & $1,550,735$ s & $1,705,673 \$$ & $1,817,713$ & $1,893,175$ & $1,985,778$ S & $2,041,343$ & $\$$ \\
\hline After-ax Income & $\$ \quad[23,682,594) \$$ & $4,337,605 \mathrm{~s}$ & $4,923,444$ & $5,372,641 \mathrm{~s}$ & $5,833,716 \mathrm{~s}$ & $6,416,578$ \$ & $6,838,065$ & $7,121,945$ & $7,470,306 \mathrm{~S}$ & $7,679,337 \mathrm{~s}$ & $\$$ \\
\hline Opportunity Cost of Capita & $13 \%$ & & & & & & & & & & \\
\hline Net Present Value of Cash Flows & $5,729,154$ & & & & & & & & & & \\
\hline $\operatorname{IRR}$ & $19.23 \%$ & & & & & & & & & & \\
\hline Effect of Benchmalk Sumplus: & 1 & 2 & 3 & 4 & 5 & 6 & 7 & 8 & 9 & 10 & 11 \\
\hline Ater-tar interest temed on Benchmark Surplus & $203,111.73$ & $200,117.94$ & $220,667.85$ & $241,085.80$ & $259,168.55$ & $277,194.08$ & $293,212.88$ & $306,951.66$ & $319,147.35$ & $327,861.87$ & 0.00 \\
\hline Increese in Benchmark Suplus & $5,979,150 \mathrm{~S}$ & {$[88,130 \mid \mathrm{S}$} & 604,943 & $601,058 \mathrm{~S}$ & 532,315 S & $530,631 \mathrm{~s}$ & 471,557 S & 404,438 & $359,014 \mathrm{~S}$ & 256,536 & $(9,651,512)$ \\
\hline Totat Distributable Eamings & 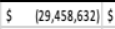 & $4,625,853 \mathrm{~S}$ & $4,539,169$ & $5,012,669 \mathrm{~s}$ & $5,560,569 \mathrm{~S}$ & $6,163,141$ \$ & $6,659,720 \mathrm{~s}$ & $7,024,459$ & $7,430,440 \mathrm{~s}$ & $7,750,663$ & $9,651,512$ \\
\hline Risk Adjusted IRR & $15.06 \%$ & & & & & & & & & & \\
\hline Net present value of Distributable eamings & $\$ 2,497,662.74$ & & & & & & & & & & \\
\hline
\end{tabular}


Journal of Global Economy, Business and Finance (JGEBF) ISSN : 2141-5595

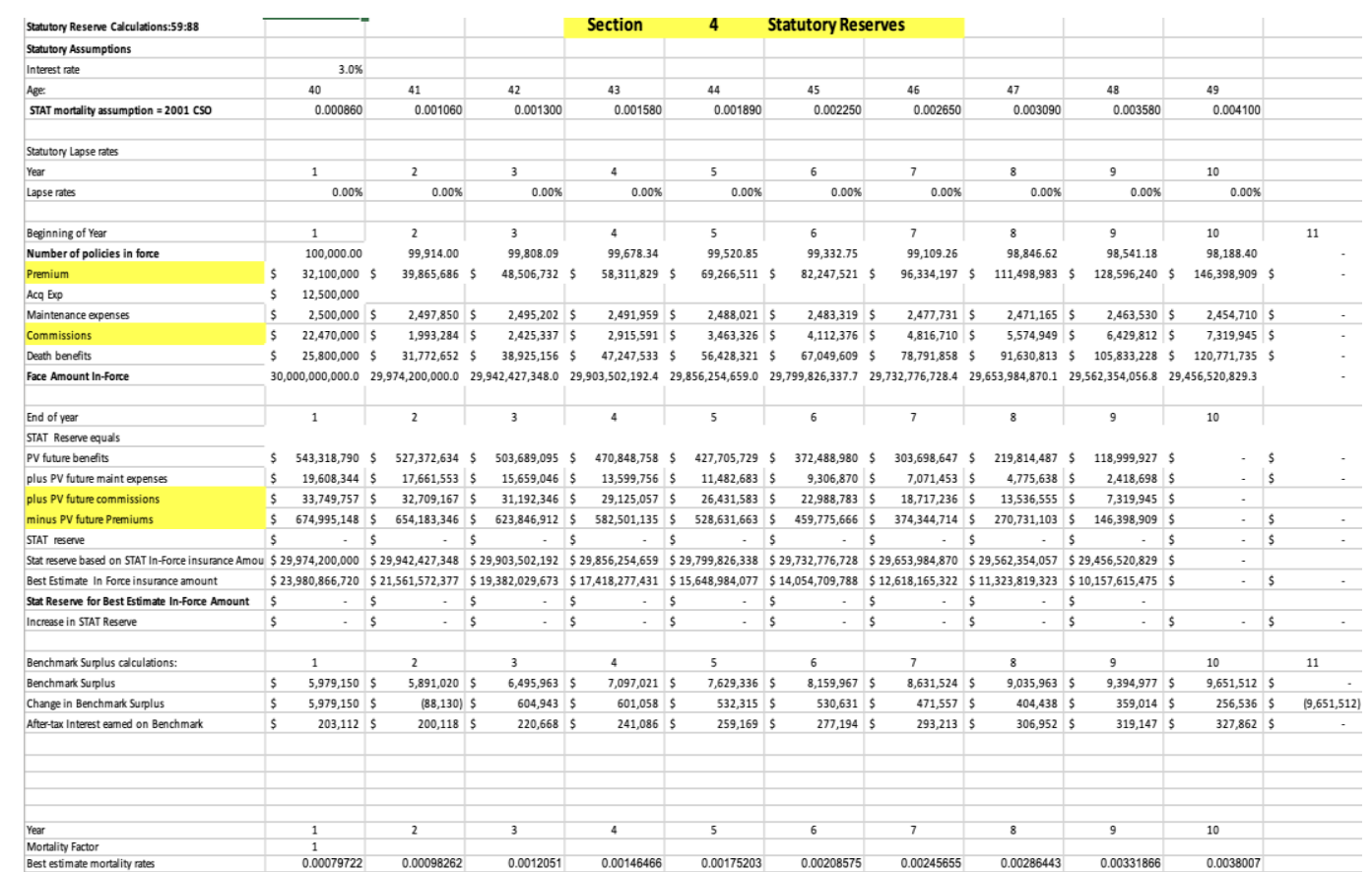

\section{Level Premium Model}

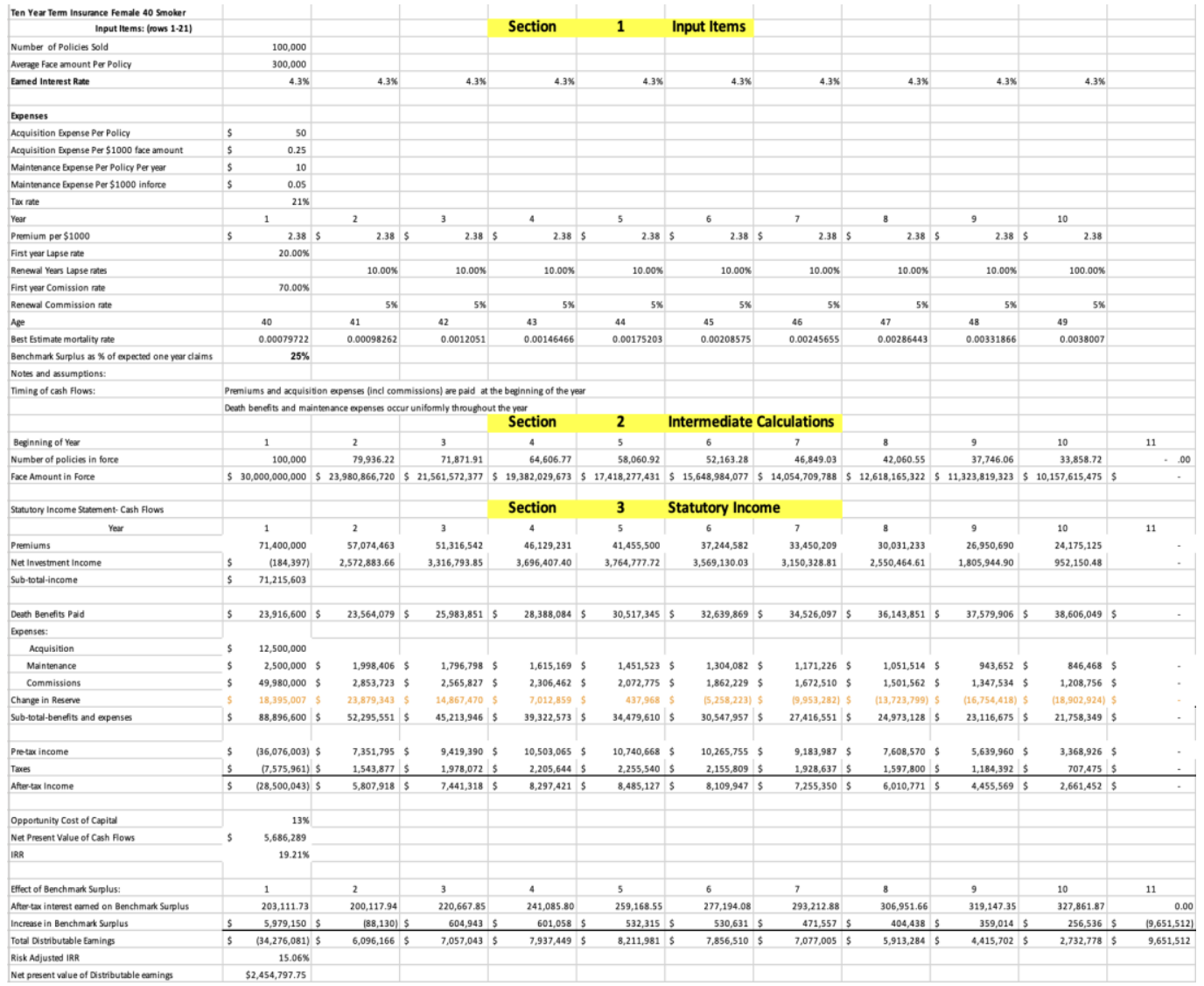

Volume 4 Issue 22022 
Journal of Global Economy, Business and Finance (JGEBF) ISSN : 2141-5595

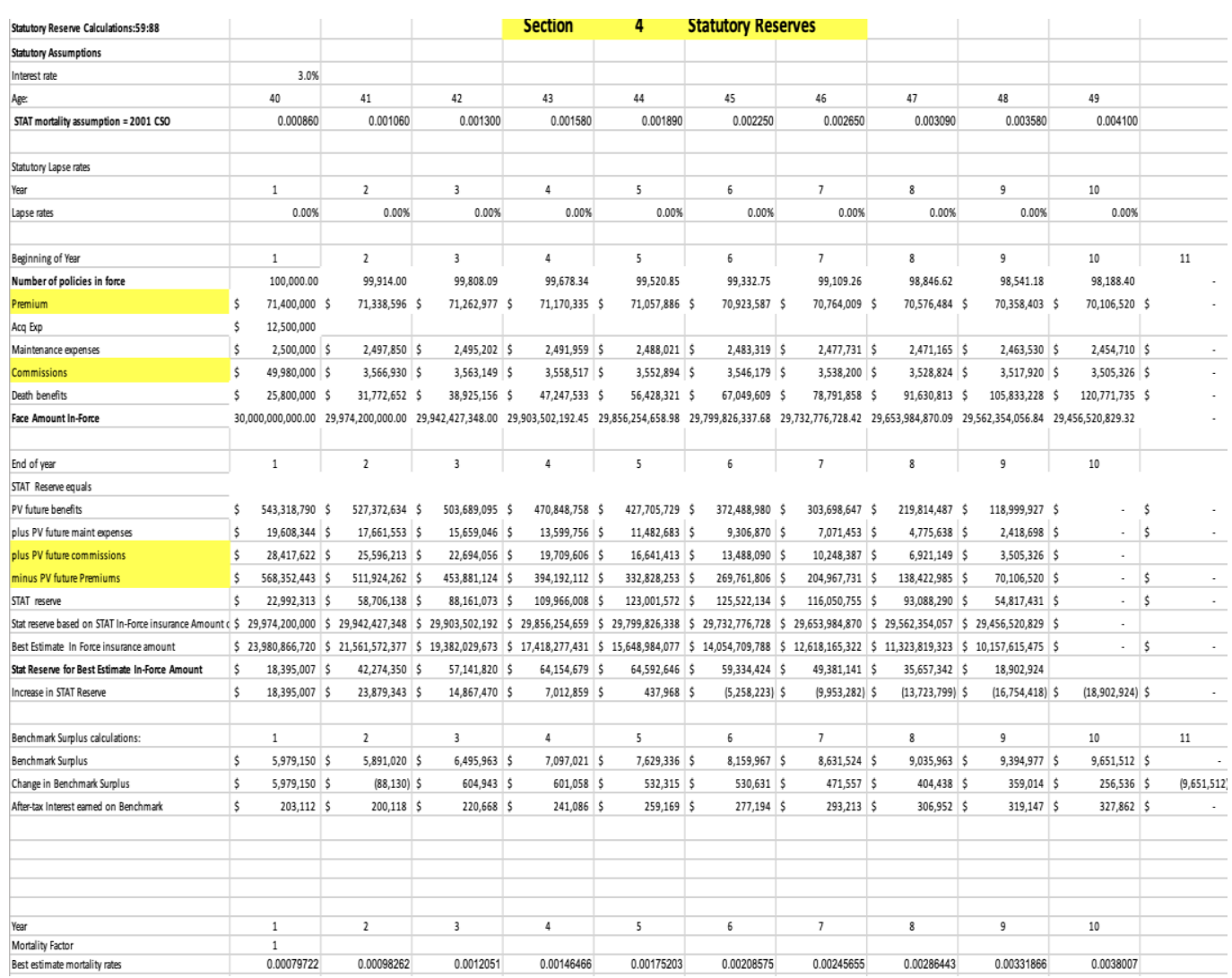

